УДК 631.53 .02

(C) 2014

Мельник А. В., доктор сільськогосподарських наук

Сумський національний аграрний університет

Собко М. Г. , кандидат сільськогосподарських наук,

Дубовик О. О. , молодший науковий співробітник

Інститут сільського господарства Північного Сходу НААНУ

\title{
ПРОДУКТИВНІСТЬ СОРТІВ ПШЕНИЦ ОЗИМӦ̈ \\ ЗАЛЕЖНО ВІД СТРОКІВ СІВБИ В УМОВАХ ПІВНІЧНОЇ ЧАСТИНИ ЛІВОБЕРЕЖНОГО ЛІСОСТЕПУ УКРАЇНИ
}

\section{Рецензент - доктор сільськогосподарських наук, професор М. Я. Шевніков}

\begin{abstract}
За результатами досліджень встановлено, щзо вищуі показники продуктивності рослин формуються за сівби в період із 10 по 20 вересня. Для більшості сортів сівба 20 вересня сприяла найбільшому прояву їх генетичного потенціалу за показниками продуктивності. Встановлена закономірність зниження продуктивності в разі відхилення строків сівби від оптимальних як у бік ранніх (10 вересня), так і пізніх (1 та 10 жовтня). Сівба у пізні строки зумовлює різке зниження продуктивності пшениці озимої. Отже, оптимальними строками сівби для умов північної частини лівобережного Лісостепу Украӥни слід вважати 10-20 вересня.
\end{abstract}

Ключові слова: пшениця озима, сорти, продуктивність, кількість продуктивних стебел, кількість зерен, маса зерен.

Постановка проблеми. За даними ФАО, у 2013 році валовий збір зерна пшениці в світі становить 674,9 млн т, в Європі - 195,4 млн тонн.

За останні три роки в Україні виробництво пшениці становить близько 16,0-22,3 млн т за рівня врожайності 2,7-3,4 т/га. У 2013 році було засіяно пшеницею озимою та ярою 6691,9 тис. га, що становить $26,08 \%$ посівних площ $[9,11]$.

В Україні провідною галуззю сільського господарства $є$ виробництво зерна, а основною зерновою культурою - пшениця озима.

Одним із основних складових вирощування озимих колосових культур є правильний вибір строків сівби.

Сівба - перший і найвідповідальніший період, який суттєво зумовлює час та повноту появи сходів, подальший ріст і розвиток рослин в осінній період вегетації, продовження фаз загартування, морозо- та зимостійкість, стійкість до інших стресових явищ, хвороб, шкідників, бур'янів, які на кінцевому етапі й $є$ визначальними факторами отримання високих урожаїв озимих культур, особливо пшениці озимої $[1,3,10]$.
Аналіз основних досліджень і публікацій, у яких започатковано розв'язання проблеми. Основа майбутнього врожаю озимих закладається за встановлення оптимальних строків сівби. Науковцями доведено, що відхилення строків сівби від оптимальних на 15-20 днів призводить до зниження продуктивності, а в результаті і врожайності, на 15-45 \% [6-8].

Мета досліджень - 3'ясувати вплив строків сівби на продуктивність сортів сучасної селекції пшениці озимої.

Завдання - визначити оптимальні строки сівби сортів пшениці озимої для умов півночі Лівобережної частини Лісостепу України.

Умови і методика проведення досліджень. Дослідження проводилися в зерно-просапній сівозміні відділу землеробства Інституту сільського господарства північного Сходу НААН. Грунт, на якому проводилися дослідження, чорнозем типовий глибокий малогумусний слабовилугуваний крупнопилуватий середньосуглинковий із такими (на період закладки досліду) агрохімічними показниками орного шару: $\mathrm{pH}$ сольової витяжки - 5,8-6,3; сума ввібраних основ - 31,2-41,7 мг-екв.; $\mathrm{P}_{2} \mathrm{O}_{5}$ і $\mathrm{K}_{2} \mathrm{O}$ (за Чириковим) - 14,8 і 11,0 мг на 100 г грунту, гумус (за Тюріним) - 4,2 \%, нітратний азот - 1,12-2,35 мг, аміачний - 0,05-0,29 мг, легкогідролізований азот $-8,4-10,9$ мг на 100 г грунту.

Умови вегетації пшениці озимої за роками досліджень суттєво різнилися між собою та багаторічними показниками. Вегетація озимих зернових восени 2010 року характеризувалася значним недобором опадів наприкінці серпня й початку вересня, холодним і дощовим періодом у жовтні, високим температурним режимом у листопаді. За сівби 1 жовтня сходи з'явилися на 20-й день, а 10 жовтня - на 15-й. На це вплинув понижений температурний режим у період «сівба сходи». У 2011 році відмічено значний недобір 


\section{СІЛЬСЬКЕ ГОСПОДАРСТВО. РОСЛИННИЦТВО}

опадів у серпні та вересні, холод на початку жовтня, який змінився на високий температурний режим у третій його декаді та першій декаді листопада. Умови початку осені викликали занепокоєння 3 точки зору вологозабезпечення. Вологозабезпечення грунту на кінець оптимальних строків сівби було незадовільним: у посівному горизонті волога була відсутня, а в 10-сантиметровому - лише 3-5 міліметрів. За таких умов сходів рослин не було отримано вчасно. Осінь 2012 року була помірно теплою, із середньою кількістю опадів. Запаси вологи в передпосівний період характеризувались як хороші й складали в посівному шарі близько 20 мм, в орному - понад 30 мм і півметровому - 81,596,4 міліметрів. За таких умов отримано повноцінні сходи за всіх строків сівби. Припинення активної вегетації рослин пшениці озимої в 2011, 2012 та 2013 роках відбулося, відповідно, 25-го, 6-го та 14-го листопада.

Характерною особливістю погодних умов 2011-2012 років була висока температура повітря та нерівномірність розподілу опадів за вегетаційний період. У 2012-2013 роках розподіл опадів був більш рівномірним, що поліпшило відносну вологість повітря й сприяло отриманню вищої продуктивності рослин порівняно $з$ іншими роками.

Технологія вирощування пшениці озимої була загальноприйнятою для даної зони. Сівбу проводили сівалкою СС-16 в агрегаті з трактором Т-25, збирання - прямим комбайнуванням комбайном «VOLVO», переобладнаним для поділянкового збирання.

Схема досліду. Фактор А - сорти пшениці озимої: Досконала, Розкішна, Подолянка, Сонечко; фактор В - строки сівби (10 вересня, 20 вересня 1 жовтня, 10 жовтня). Параметри досліду: $\mathrm{la}=4,1 \mathrm{~s}=4 ; \mathrm{n}=4$. Розміщення ділянок - систематичне. Посівна площа ділянок $-28 \mathrm{~m}^{2}$, а облікова $-24 \mathrm{~m}^{2}$. Повторність у дослідженнях - триразова.

Супутні аналізи та обліки проводили за загальноприйнятими методиками: відбір снопового матеріалу здійснювали за один-два дні до початку збирання врожаю 3 площі 0,25 м² у чотирьох місцях ділянки; структурний аналіз врожаю проводився за «Методикою державного сортовипробування сільськогосподарських культур» [4-5]. Статистична обробка отриманих результатів врожайності проводилася методом дисперсійного аналізу згідно з методикою Б. О. Доспєхова за допомогою некомерційних комп'ютерних програм типу STATISTICA, SPSS та інших [2].
Результати досліджень. За роки проведення дослідження на посівах пшениці озимої встановлено параметри формування елементів продуктивності рослин залежно від сортових особливостей, строків сівби та виявлено їх відмінності. 3-поміж досліджених сортів у середньому на варіантах найвищими були рослини сорту Сонечко (88,3 см). Істотно меншою висотою характеризувалися рослини сорту Розкішна (78,1 см), за $\mathrm{HIP}_{05}=3,9$ см. У розрізі строків сівби висота варіювала в межах 87,0-93,3 см (за сівби 10 вересня), 84,0-93,0 см (20 вересня), 70,3-86,7 см (1 жовтня) та 70,7-80,0 см (10 жовтня). Відмічено суттєве зниження висоти рослин у міру запізнення 3 сівбою, після 20 вересня $\left(\mathrm{HIP}_{05}=7,5 \mathrm{~cm}\right)$. Максимальний показник висоти рослин зафіксовано у сорту Сонечко за сівби 20 вересня в 2012 році - 105,3 сантиметрів. Відповідно, й у інших сортів вищі рослини було відмічено за сівби 20 вересня, що свідчить про сприятливі умови для росту й розвитку рослин саме за цього строку сівби.

Під час формування врожайності важливим показником впливу на їі величину є густота продуктивного стеблостою, яка в нашому дослідженні залежала від сорту і строків сівби. Серед досліджених сортів у середньому на варіантах найвищу густоту продуктивних стебел було сформовано рослинами сорту Подолянка (433,3 шт./м²), найнижчу - Досконала (399,7 шт./м²). Слід відзначити більш виражену реакцію на зміну строків сівби у сорту Подолянка, в якого даний показник варіював від 312,3 до 500,7 шт./м².

Найбільша кількість продуктивних стебел у основної маси сортів відмічена за сівби 10-го та 20-го вересня, що вказує на високу здатність до продуктивного кущення саме за цих строків сівби. Формування найбільшого продуктивного стеблостою встановлено у сорту Досконала

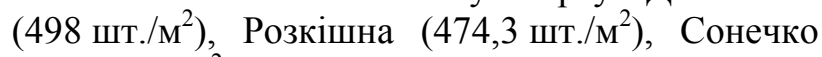
(436,0 шт./M²) за сівби 10 вересня, а в сорту По-

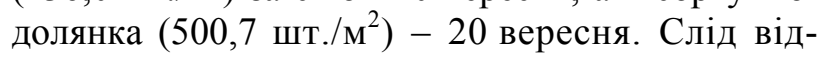
значити, що сівба в надпізні строки (1-10 жовтня) призвела до істотного зниження даного показника.

Дослідженнями встановлено, що менша кількість зерен із колосу отримана в посушливому 2011 році (27,7-39,7 шт./колос). У середньому на варіантах найвищу кількість зерен у колосі було сформовано рослинами сорту Розкішна та Сонечко (34,7-34,8 шт.), найнижчу - Подолянка (31,7 шт.). Для основної маси сортів сівба 20 вересня гарантувала отримання озерненості колосу на рівні 30,7-39,7 штук. 
СІЛЬСЬКЕ ГОСПОДАРСТВО. РОСЛИННИЦТВО

Показники продуктивності сортів пшениці озимої за різних строків сівби (середнс за 2011-2013 рр.)

\begin{tabular}{|c|c|c|c|c|c|}
\hline $\begin{array}{c}\text { Сорт } \\
\text { (фактор A) }\end{array}$ & $\begin{array}{c}\text { Строк сівби } \\
\text { (фактор В) }\end{array}$ & Висота, см & $\begin{array}{c}\text { Кількість продук- } \\
\text { тивних стебел, } \\
\text { шт./м² }\end{array}$ & $\begin{array}{c}\text { Кількість зерен } \\
\text { у колосі, } \\
\text { шт./колос }\end{array}$ & $\begin{array}{l}\text { Маса зерен } \\
\text { із колосу, г }\end{array}$ \\
\hline \multirow{4}{*}{ Досконала } & 10 вересня & 93,0 & 498,3 & 29,6 & 1,46 \\
\hline & 20 вересня & 84,0 & 420,0 & 38,5 & 1,91 \\
\hline & 1 жовтня & 81,3 & 370,7 & 32,0 & 1,51 \\
\hline & 10 жовтня & 75,0 & 309,7 & 31,0 & 1,49 \\
\hline \multirow{4}{*}{ Розкішна } & 10 вересня & 87,0 & 474,3 & 33,8 & 1,54 \\
\hline & 20 вересня & 85,0 & 422,3 & 39,7 & 1,91 \\
\hline & 1 жовтня & 70,3 & 416,3 & 34,1 & 1,57 \\
\hline & 10 жовтня & 71,7 & 370,7 & 31,3 & 1,43 \\
\hline \multirow{4}{*}{ Подолянка } & 10 вересня & 90,0 & 458,7 & 32,5 & 1,56 \\
\hline & 20 вересня & 86,7 & 500,7 & 30,7 & 1,45 \\
\hline & 1 жовтня & 73,0 & 461,3 & 27,7 & 1,31 \\
\hline & 10 жовтня & 77,7 & 312,3 & 36,0 & 1,59 \\
\hline \multirow{4}{*}{ Сонечко } & 10 вересня & 93,3 & 436,0 & 36,3 & 1,58 \\
\hline & 20 вересня & 93,0 & 430,3 & 38,1 & 1,74 \\
\hline & 1 жовтня & 86,7 & 421,0 & 33,2 & 1,57 \\
\hline & 10 жовтня & 80,0 & 341,7 & 31,6 & 1,45 \\
\hline \multirow{3}{*}{$\mathrm{HIP}_{05}$} & фактор A & 3,9 & 36,9 & 2,6 & 0,11 \\
\hline & фактор В & 7,5 & 54,6 & 4,7 & 0,26 \\
\hline & фактор AB & 10,9 & 93,2 & 7,3 & 0,33 \\
\hline
\end{tabular}

За масою зерен із колосу сорти пшениці озимої суттєво не відрізнялися. Спостерігалося певне зменшення маси зерен із колосу в сорту
Подолянка. Зауважимо, що в основної маси сортів вищі показники маси зерен із колосу відмічені в 2012 та 2013 роках (див. рис.).

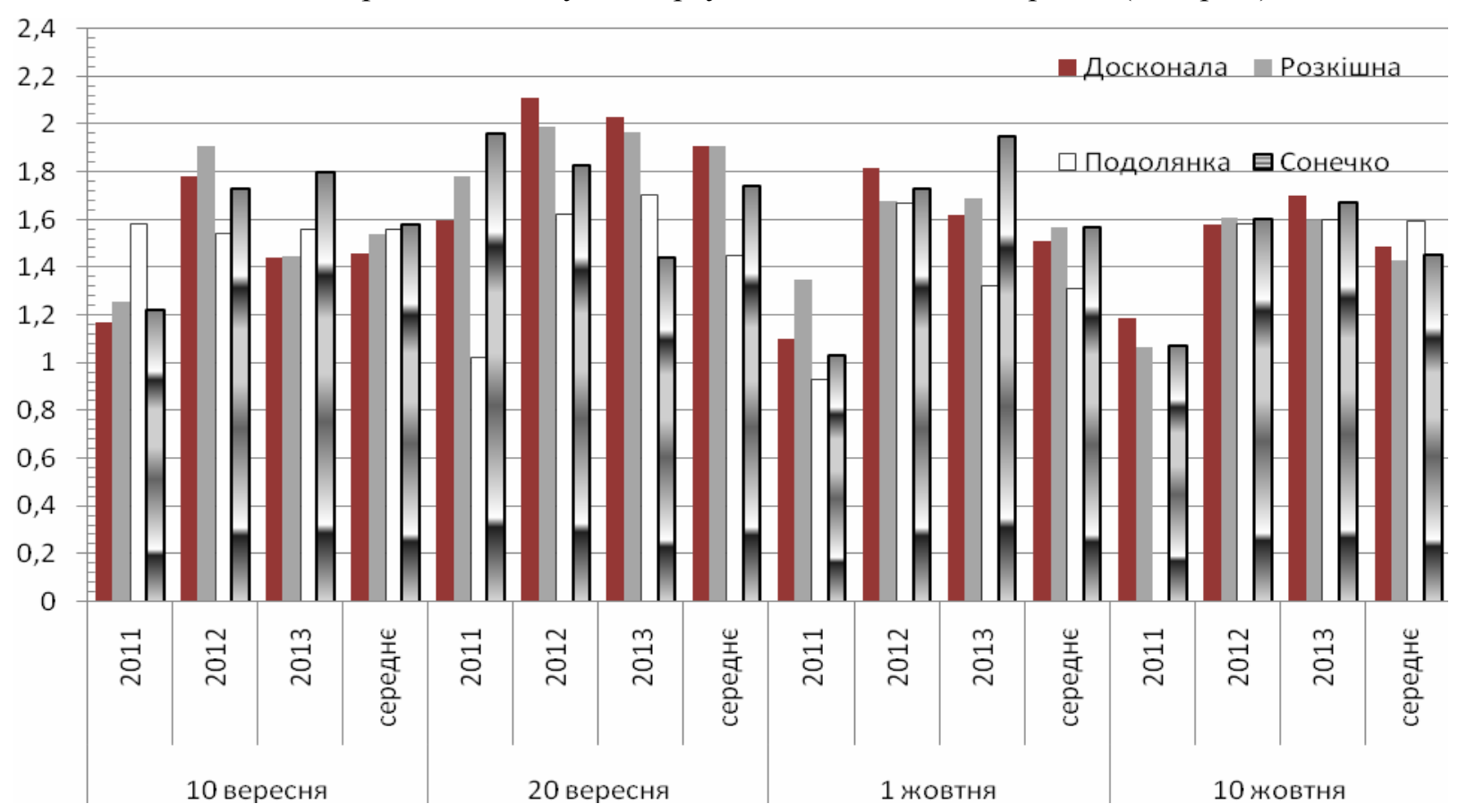

Рис. Показники маси зерен із колосу рослин пшениці озимої залежно від строків сівби, 2 (2011-2013 pp.) 


\section{СІЛЬСЬКЕ ГОСПОДАРСТВО. РОСЛИННИЦТВО}

На основі одержаного експериментального матеріалу було встановлено різну реакцію сортів пшениці озимої на строки сівби. У трьох сортів пшениці озимої (Досконала, Розкішна, Сонечко) найвищі показники маси зерен iз колосу (1,8-1,9 г) сформувалися за сівби 20 вересня. У сорту Подолянка найбільшу масу зерна 3 колосу було отримано за сівби в ранній період (10 вересня). Запізнення з сівбою обумовлювало зниження даного показника продуктивності.

Результати проведених досліджень свідчать про тенденцію формування вищих показників продуктивності рослин пшениці озимої, посія-

\section{БІБЛІОГРАФІЯ}

1. Звягін А. Ф. Особливості селекції сортів пшениці озимої універсального типу з підвищеним адаптивним потенціалом у східному Лісостепу України / А. Ф. Звягін, 3. В. Усова [та ін.] // Вісник ЦНЗ АПВ Харківської області, 2012. C. 89-94.

2. Комп'ютерні методи в сільському господарстві та біології: навчальний посібник О. М. Царенко, Ю. А. Злобін, В. Г. Скляр [та ін.]. Суми : Університетська книга, 2000. - 203 с.

3. Лебідь $C . M$. Наукові основи підвищення ефективності виробництва зерна в Україні / С. М. Лебідь, М. С. Шевченко // Бюлетень інституту зернового господарства. - Дніпропетровськ : Інститут зернового господарства, 2008. - № 3334. - C. 3-7.

4. Методика проведення експертизи та державного випробування сортів рослин зернових, круп'яних та зернобобових культур. - К., 2003. Вып. 2. - Частина 3. - С. 193-199.

5. Методичні вказівки щодо проведення польових досліджень і вивчення технології вирощування зернових культур. - Чабани : Інститут землеробства УААН, 2001. - 22 с. них в оптимальні строки.

Висновок. Встановлено, що вищі показники продуктивності рослин (кількість продуктивних стебел, кількість і маса зерен із колосу) формуються за сівби в період із 10 по 20 вересня. Для більшості сортів сівба 20 вересня сприяла найбільшому прояву їх генетичного потенціалу.

Отже, оптимальними для умов північної частини Лівобережного Лісостепу України строками сівби слід вважати 10-20 вересня. Сівба у пізні строки зумовлює різке зниження продуктивності пшениці озимої.

6. Наукові основи агропромислового виробництва в зоні Лісостепу України / [В. М. Зубець]; За ред. В. М. Зубця. - К. : Логос, 2004. - 776 с.

7. Дем'яненко В. В. Вплив строків сівби на рівень продуктивності зерна та насіння сучасних сортів озимої пшениці. Сайт ТОВ «Агроскоп Україна» [Електронний ресурс]. - Режим доступу : http://agroscop.com.ua/ua/news/54.html.

8. Hemic I. Оптимізація строків сівби пшениці озимої. Сайт «Пропозиція» [Електронний ресурс]. - Режим доступу : http: // propozitsiya.com/ ?page $=146 \&$ itemid $=3403$

9. Площі зернових та олійних культур. Урядовий портал. Сайт Міністерства аграрної політики та продовольства України [Електронний ресурс]. - Режим доступу : http//www.minagro.kiev.ua.

10. Програма Зерно України -2015. Сайт Національної академії аграрних наук України [Електронний ресурс]. - Режим доступу: http:/www.uaan.gov.ua/sites/default/files/zerno.doc.

11. Food and agriculture organization of the United Nations. FAO [Електронний ресурс]. - Режим доступу : http://faostat.fao.org/site/636/default.aspx\#ancor. 